International Journal of Instruction e-ISSN: 1308-1470 • www.e-iji.net

Article submission code: 20200119042503

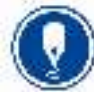

Received: $19 / 01 / 2020$ Revision: 17/10/2020
April $2021 \bullet$ Vol.14, No.2

p-ISSN: 1694-609X

pp. 735-756

Accepted: 09/11/2020

OnlineFirst: 26/02/2021

\title{
Improving Students' Academic Achievement Using the ScEd-ALS Android-Based
}

\section{Z. Zulfiani}

Dr, Department of Biology Education, Syarif Hidayatullah State Islamic University, Jakarta, Indonesia,zulfiani@uinjkt.ac.id

Iwan Permana Suwarna

M.Pd, Department of Physics Education, Syarif Hidayatullah State Islamic University, Jakarta, Indonesia, iwan.permana.suwarna@ uinjkt.ac.id

\section{Sujiyo Miranto}

Dr, Department of Biology Education, Syarif Hidayatullah State Islamic University, Jakarta, Indonesia, sujiyo.miranto@uinjkt.ac.id

Ubiquitous learning has recently gained increasing popularity in the education sector, which significantly increased the efficiency of individual and collaborative learning. The aim of this study is to develop an Android version of science education-adaptive learning system (ScEd-ALS) as a science learning medium to accommodate various learning styles. The method used in this research is a mixedmethod consisting of a qualitative method, which is a developmental method that provides illustrations concerning the process of creating the developed media, and a quantitative method, which utilizes quasi-experiments to determine the effectiveness of the developed media application. The study comprised 114 eighthgrade junior high school students and three integrated science teachers in South Tangerang. The final product of the study is an Android-based science learning medium that conforms to the visual, aural, reading/writing, and kinesthetic student learning styles. Hence, this Android-based ScEd-ALS was found to be feasible and useful, as assessed by five experts (two media experts and three science education material experts). Nonetheless, there were significant differences in the learning outcomes between the experimental class using the Android version of ScEd-ALS compared to the control class. The effectiveness of using ScEd-ALS in this study was measured based on the percentage of students' mastery level. ScEd-ALS Android based on visual and kinesthetic learning styles are the most effective media compared to aural and read/write.

Keywords: adaptive learning system, science learning media, Android, learning style, ubiquitous learning

Citation: Zulfiani, Z., Suwarna, I. P., \& Miranto, S. (2021). Improving Students' Academic Achievement Using the ScEd-ALS Android-Based. International Journal of Instruction, 14(2), 735756. https://doi.org/10.29333/iji.2021.14241a 


\section{INTRODUCTION}

Internet-based technologies have become an important part of everyday life. Referred to as the "digital era," this Internet-based technology era has various interrelationships with communication, data exchange, and telematic systems (O de Pietro, 2013; Wen \& Liu, 2016). One product of this digital era is e-knowledge (Norris, Mason, \& Lefreve, 2003), that is, knowledge products that utilize information technology to provide information to others. This e-knowledge is an important component in building the culture of digital literacy for everyone, including the education field. Transformation of technology, including the field of education, has significantly changed the way of learning and teaching. Dwi (2016), throughout her many years of research, reported that the development of cellular technology in the world of education has undergone some adaptation (i.e., changes in the learning environment that are different from the previous ones). Cooperative learning designs are even more adaptive, in which students learn more independently using smartphones and collaboration Think Pair Share (TPS) Leaning Model with Android-based m-Learning affects understanding trigonometric concepts in pre-service teachers (Jelatu, Kurniawan, Kurnila, Mandur, \& Jundu (2019).

It has been reported in several scientific studies that it is important to prepare children in the digital age as digital media encourage students to think critically and active learning allows them to control what they will do (Van De Bogart, 2012). There are various reasons why mobile devices can empower communication and interactions between teachers and students in undeveloped areas. This includes the speed of obtaining information with high penetration, ownership, and portability (Valk, Rashid, \& Elder, 2010; Arista \& Kuswanto, 2018). Mobile devices have become a key tool for both students and educators because they are interesting for developing mobile-platformbased learning material (Tigrek \& Obadat, 2012). Adaptation to various learning styles is crucial for designing mobile learning technologies. Every student is different and each has his/her own individual interests (FernáNdez-LóPez, RodríGuez-FóRtiz, RodríGuezAlmendros, \& MartíNez-Segura, 2013; de-Marcos, Hilera, Barchino, Jiménez, Martínez, Gutiérrez, ... \& Otón, (2010). Long-term memory and retention are enhanced when individuals recognize the teaching mode preferences or the way students learn (Pashler, McDaniel, Rohrer, \& Bjork, 2008; Pham, 2012; Klašnja-Milićević, Vesin, Ivanović, \& Budimac, 2011; Birch, Sankey, \& Gardiner, 2010). Moreover, Dunn, Beaudry, and Klavas (2002) stated that student learning outcomes increase when the teaching method conforms to their learning style. Learning styles are very important in improving the learning outcomes (Liu \& Chu, 2010; Klašnja-Milićević, Vesin, Ivanović, \& Budimac, 2011; Pruet, Ang, \& Farzin, 2016).

Farida, Jumadi, Wilujeng, and Senam (2018) reported the development of Android as an effective medium for teaching in Indonesia, using global warming as a topic, to improve the scientific literacy of junior high school students. Utilizing Android-based learning is currently trending as the application of learning of the 21st century (Calimag, Mugel, Conde, \& Aquino, 2014; Liliarti \& Kuswanto, 2018; Astiningsih \& Partana, 2020). In a survey study of 605 people in three major cities in Indonesia, Puspitasari and Ishii (2016) reported that young people with high levels of education tend to use cellular 
Internet on their smartphones. Smartphones are used intensively in everyday life for information acquisition (Sunarto, Hariadi, Sagirani, Amelia, \& Lemantara, 2020)

Current media are generally informative by providing evaluation questions and are general in nature according to the program designer/certain base of learning models. In addition, current media are not reserved for slow learners and do not provide additional supplements to fast learners, and they do not exist specifically according to the students' learning styles. It is clear that technology is growing rapidly in Indonesia, as shown by the fact that Indonesia ranks seventh worldwide among smartphone users, or fourth in the Asia Pacific region (eMarketer, 2014). Smartphones, however, still have a potential that has not been widely unlocked, particularly in education, and there are no sufficient studies on that matter. Cellular computation allows the distribution of subject material that can be used in independent teaching, with an unlimited space-time access (ubiquitous learning) (Hwang, Chu, Chen, \& Cheng, 2014; Ako-Nai, Qing, Pivot, \& Kinshuk, 2012).

One of the solutions to overcome the aforementioned problem is to use an adaptive learning system (ALS) with a hypermedia system on an Android smartphone platform. This way of learning can support individual learning. Learning using ALS media provides an information platform tailored to individual differences in both cognitive and learning styles (Al-Azawei \& Badii, 2014). There is a need for a smartphone-based science education ALS (ScEd-ALS) science learning medium (Android/iOS) that fits the aural, visual, reading/writing, and kinesthetic learning styles of students. In addition, the resulting media do not provide additional burdens for teachers. Moreover, remedial teaching can be performed outside school facilities (i.e., at each student's home). This can alleviate the teachers' burdens and help the students with material preparation with a well-prepared stimulus (Balakrishnan \& Gan, 2016).

The learning conducted at schools is still following the single learning style approach. Teachers provide learning material according to what they consider good, instead of according to the students' needs. Students with different learning styles may have different learning approaches (Baeten, Dochy, Struyven, Parmentier, \& Vanderbruggen, 2015; Balakrishnan \& Gan, 2016).

Once the teacher succeeds in identifying his/her students' learning styles, this will direct the teacher to vary the teaching strategies (Magdalena, 2015). Zulfiani, Suwarna, and Miranto (2018) developed a computer-based ScEd-ALS as a science learning medium based on variations in student learning styles for remedial offline teaching.

Researchers developed the ScEd-ALS model using a hypermedia design at the prototyping stage with a computer-based flash platform. At this prototyping stage, they obtained input from media experts in the form of advice for development; besides the form of a compact disc (CD), a smartphone version is also needed. In a survey by Suwarna (unpublished work, 2017), it was shown that $96.94 \%$ of the students in South Tangerang owned smartphones (out of a total of 359 respondents). This fact has also became a challenge for the development and effectiveness of ScEd-ALS media if it developed into a smartphone version (Android/iOS) suitable with the student's 
circumstances in Indonesia. ScEd-ALS, which has been developed in the form of a CD, contains material for eight-grade science (i.e., a motion system concept that integrates biology and physics). In this material, incompleteness at school was frequently found. Nearly $60 \%$ of the students have to sit for remedial tests in relation to this concept, and this occurred among students with various learning styles (Zulfiani et al., 2018). The incompleteness of comprehension in this material may fatally impact the understanding of the material at the next level, which may in turn result in unsatisfactory scores in the final exam.

Many technical drawbacks were found in the implementation of the prototyping stage in computer-based ScEd-ALS media for small groups. Students face some difficulties in operating media because these media require a laptop or a personal computer (PC) with a low level of mobility. Laptops and PCs are heavier and, thus, difficult to carry or move around. This technical drawback results in suboptimal use of the program ScEd ALS. Laptops require a long-startup program, which is deemed tiring for impatient students. Laptops have high electrical power consumption and, hence, require an electric socket to charge their batteries, and they are not compatible with power banks like cellphones are, and this is problematic especially when working on applications that require the use of the touchpad or a mouse. Technical constraints can cause suboptimal use of the program. Unlike PCs and laptops, smartphones are more energy efficient and have a high level of mobility, allowing these devices to have a great potential for users/students to use the program in any place they consider comfortable. $80 \%$ of the most widely used applications are on mobile phones (Echenique, Molías, \& Bullen, 2015). Thus, the developed application must be compatible with the Android system. Lack of optimal use in the ScEd-ALS media using a PC or a laptop on the prototyping stage may reduce the influence of the media on the expected learning outcomes. This is suggested to be a factor that influences the results. Efforts are needed to minimize the technical constraints so that the benefits of the ALS as a science medium can improve the student learning outcomes more optimally.

\section{Research objectives}

(1) To develop an ScEd-ALS (ubiquitous learning) as a science learning medium to accommodate various learning styles.

(2) To measure students' academic achievement after using the ScEd-ALS as a science learning medium with various learning styles.

\section{METHOD}

The research method used in this study is a mixed-method, namely, combining a qualitative and a quantitative method. The qualitative method used is the development method that serves to provide an overview concerning the process of making the developed media.

On the other hand, the quantitative method utilizes quasi-experiments to determine the effectiveness of the application results of the developed media. The two-phase research development method in this study utilizes the stages of Akker (2006). The summative 
evaluation stage is a stage at which the quantitative method is utilized through the use of quasi-experiments with a nonequivalent pretest/posttest group design (Cohen, Manion, \& Morrison, 2011).

This study uses three schools in the $8^{\text {th }}$ grade of SMP A, MTS B, and MTS C. SMP is a junior high school, and MTS is the level of education of junior high school. The research sample of SMP/MTS students in South Tangerang concerning specific characteristics (purposive sampling technique). The rationale for issuing school selection, i.e.: (1) Schools with readiness to share Information and Computer Technology (ICT) devices, such as wifi, and allow students to bring smartphones as learning resources, (2) Schools that apply the curriculum of 2013 where Science Learning is designed with Integrated Science settings, and (3) have learned material that requires research material.

\section{Development method}

The research procedure for studying science learning media (i.e., Android version of ScEd-ALS on motion, e.g., frame and muscle) and simple machine materials consists of four stages.

The first stage is preliminary research, which includes literature studies and field studies. Literature studies were carried out in the form of analyzing the search results of computer-based ScEd-ALS research developed, as well as analyzing the relevant research and surveys related to science learning and the condition of science learning styles among students at schools. The aims of these literature studies are to acknowledge the problems that occur and to obtain information on the conditions of the learning styles and student responses to the learning media used by teachers.

The second stage is to create product samples (prototyping stage) for the Android version of ScEd-ALS with a variety of student learning styles. The generated prototype is the result of a literature study on the computer-based ScEd-ALS media developed, which can accommodate diverse visual, aural, reading/writing, and kinesthetic learning styles in science materials for grade eight. The review results from the study recommendations were the Android version of the ScEd-ALS media. At this stage, a product design trial is carried out through formative evaluation. The results of this formative evaluation are used to technically improve the media prototypes. The stages of this prototype include program design/media design (concept design, program flowchart) and optimization of the prototype design (software selection, procedures for media generation, formative evaluation, and revision). The design phase of the science learning media consists of several stages, including concept design and program flowchart.

Figure 1 is a concept from the Android version of the ScEd-ALS media that was developed, referring to the results of a study conducted by researchers in 2017 and modified from the intelligent ALS of Lemke (2013). Students are tested for their learning variations before learning using this science learning medium. The learning variation test used in this study is Fleming's VARK model (Fleming, 2017). The media are equipped with the following menus: material, sample questions, material summaries, 
and exercises. The materials in this study included a fixed pulley; a free pulley; a compound pulley; pivot wheels; an inclined plane; type 1, 2, and 3 levers; a human skeleton; bone reinforcement; joints; muscles; bone disorders; joint disorders; and muscle disorders. These materials are shown in the flowchart in Fig. 2.

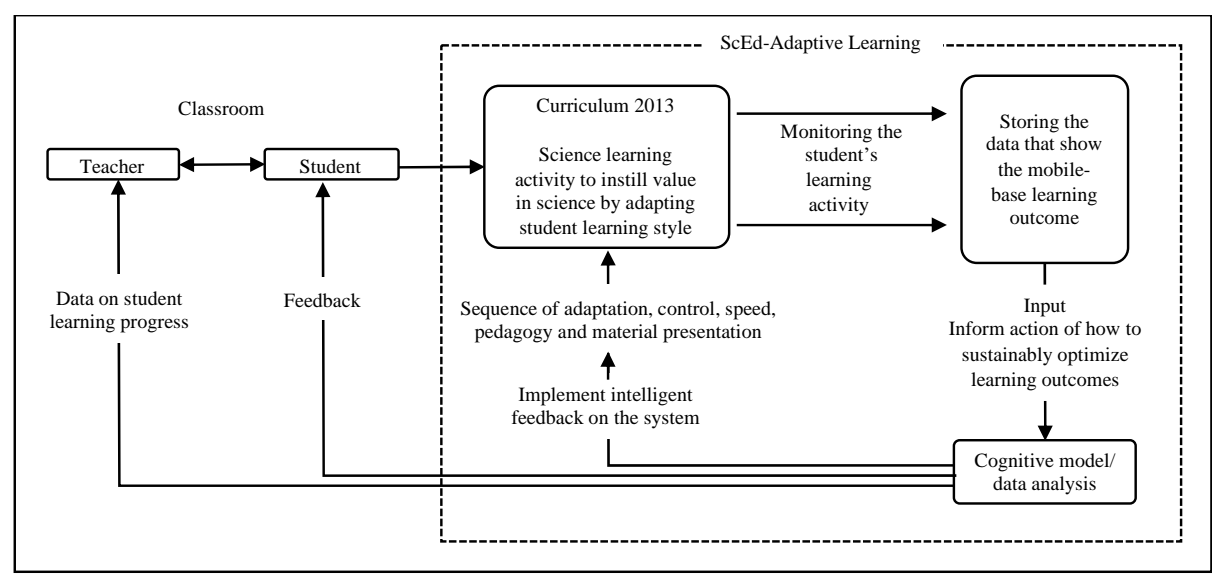

Figure 1

Design of the ScEd-ALS learning media (modified from Lemke, 2013)

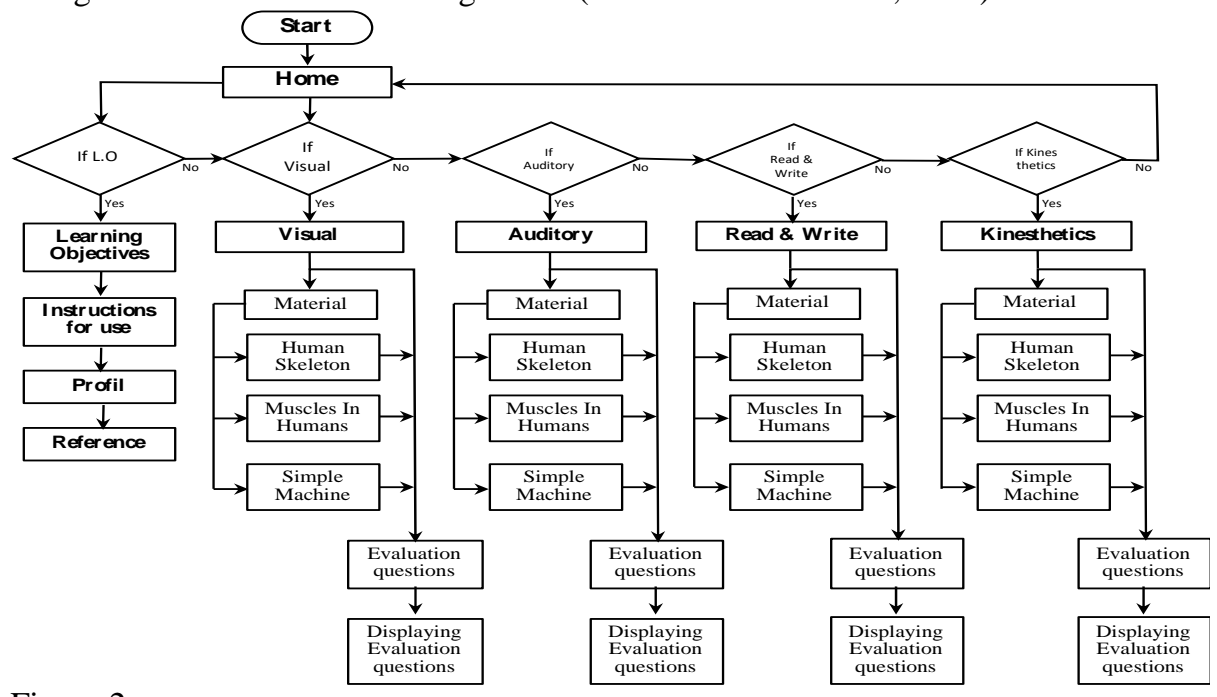

Figure 2

Flowchart of the media ScEd-ALS.

\section{Design trials}

Product or prototype trials are carried out at the formative and summative evaluation stages. A trial was conducted to determine the level of feasibility of the developed learning media and the improvement of product quality. This product trial utilized 
formative evaluation. The formative evaluation used is Tessmer's formative evaluation (1993), which consists of expert review, one-to-one evaluation, small group evaluation, and a field study (Figure 3).

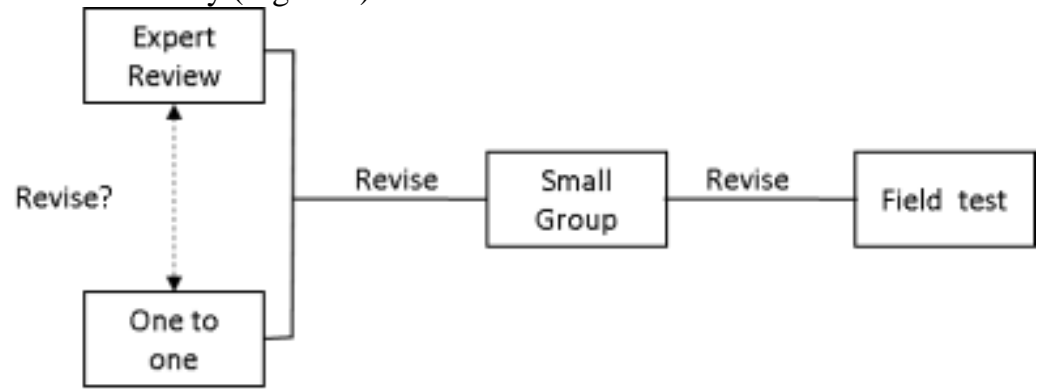

Figure 3

Tessmer's formative evaluation

The prototyping stage is carried out in three steps: the first step is to carry out expert and one-to-one evaluations; the second step is done through small group evaluation, and the third step is carried out in a field test. After field testing, the researchers made some improvements to the product, and then a summative evaluation was carried out to test its effectiveness and practicality.

The first phase of the product trial is an expert review and one-to-one evaluation. An expert review is an expert assessment of media, whereas a one-to-one evaluation is a media evaluation that is tested on certain students. At this stage of the expert review, the research media prototype was assessed by three material experts and two media experts. At the one-to-one evaluation phase, the media were tested by 12 from 51 students $8^{\text {th }}$ grade of SMP A South Tangerang, in which the students were asked to assess the temporary product of the developed media. The determination of 12 people is based on the ability of high, medium, and low category students. Subsequently, a revision was conducted for the Android version of the ScEd-ALS science learning media.

The second phase of the trial is a small group evaluation. The product, as revised in the first stage, is tested for a small group of students. The aim of this trial is to obtain an evaluation of the revised product. Small groups of students were inquired to assess the revised media. At this stage, a trial was conducted on 23 students of South Tangerang SMP A with different students from 12 students in the previous phase. The trial results at this stage were studied to make improvements in the second phase.

The third phase of the product trial is the field test. Field testing is the stage of product trial in the field. The prototype tested at this stage is considered a prototype that meets all the criteria and is the result of several improvements from previous revisions.

There are six parallel classes (120 students) $8^{\text {th }}$ grade with two groups of four regular courses and two bilingual courses. Based on school considerations and students' readiness to use smartphones as learning resources, researchers conducted field test steps involved 24 of 48 bilingual students of South Tangerang MTS B. 
The results of this third step of revision of the prototype will be tested/evaluated for its practicality and effectiveness on 50 students of South Tangerang MTS C. MTS C has 11 parallel classes $8^{\text {th }}$ grade with an average number of 25 students with three science teachers. Sampling was done by purposive sampling by considering the same teacher teaching in the class and having homogeneous abilities. The results of these considerations were chosen by two classes, which were then randomized to determine the experiment and control classes.

The third stage is the summative evaluation stage, the stage at which the effectiveness and practicality of the developed learning media prototype are determined. The effectiveness of the product can be identified by administering posttests to students and calculating the percentage of student completion with the minimum completeness criteria. In order to identify the practicality of the product, teachers and students were required to fill in a response questionnaire regarding the practicality of the media.

The fourth stage is the stage of systematic reflection and documentation, which is the final stage in Akker's development procedure. This stage describes the entire process of developing the science learning media, starting from the analysis of preliminary studies, as well as documents on media-making processes starting from design, specifications, principles, and conceptual relations systematically narrated, thereby illustrating the research process and flow.

\section{Instruments}

The instruments used in this study were tests and non-tests (Table 1).

Table 1

Instruments, objectives, and sources of data.

\begin{tabular}{|c|c|c|c|}
\hline $\begin{array}{l}\text { Research } \\
\text { step }\end{array}$ & Instrument & Purpose(s) & Data \\
\hline \multirow[b]{2}{*}{ 营 } & VARK instrument & Determining the learning style & Student \\
\hline & $\begin{array}{l}\text { Teacher and } \\
\text { student interview } \\
\text { guidelines }\end{array}$ & $\begin{array}{l}\text { Obtaining information related to science } \\
\text { studying and problems associated with the } \\
\text { study of science in grade eight of SMP/MTS } \\
\text { and the use of study media at schools }\end{array}$ & Teacher \\
\hline \multirow{2}{*}{ 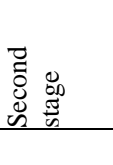 } & $\begin{array}{l}\text { Media assessment } \\
\text { questionnaire }\end{array}$ & Measuring the validity of the developed media & $\begin{array}{l}\text { Media experts and } \\
\text { science experts }\end{array}$ \\
\hline & $\begin{array}{l}\text { User response } \\
\text { questionnaire }\end{array}$ & $\begin{array}{l}\text { Measuring the effectiveness and practicality } \\
\text { of media }\end{array}$ & Student \\
\hline 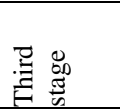 & Test & Concept mastery & Student \\
\hline
\end{tabular}

The VARK instrument is used to determine the student learning styles as information regarding the learning style profiles that appear in eighth-grade students. The number of items is 16 , consisting of four options; each option is related to the characteristic of visual, aural, reading/writing, and kinesthetic learning styles (Fleming, 2017).

Guidelines for interviewing teachers and students are used to obtain information about problems regarding science learning in grade eight and learning styles at schools, as well 
as the use of instructional media at schools. Meanwhile, instrument validation is an assessment questionnaire given to media experts and material experts by expert judgment. The applied questionnaire is a rating scale with five rating categories $(4,3,2$, 1 , or 0$)$. Experts first conduct a validation of the ScEd-ALS media products on simple machine materials and motion body parts (muscles, skeletons). The products are then divided into the following four categories: visual-type ScEd-ALS media product, auraltype ScEd-ALS media product, reading/writing-type ScEd-ALS media product, and kinesthetic-type ScEd-ALS media product. Each product consists of four subconcepts.

The aspects of material validation include (1) the suitability of pictures, animations, observation videos, and explanatory videos related to the material; (2) clarity in explaining physics formulas and organ parts through text or video explanations on the material; (3) clarity of the sample questions in each material; (4) accuracy in answering the evaluation questions on each material; (5) accuracy of the presentation (systematic) without misconceptions in each material; and (6) scope and depth of the material. The material validation aspects include software engineering and communication, as well as visuals and media.

An instrument was utilized to determine the effectiveness and practicality of the media through responses given by the users of the products developed. This instrument uses a questionnaire in the form of a rating scale (multilevel scale) with five categories $(4,3,2$, 1 , or 0 ) given during the summative evaluation. In addition to using the response questionnaire from the users, effectiveness is also determined from the test results of the students who operated the science learning media. The effectiveness of the results is calculated according to the percentage of student mastery level and student response using android media.

Effectiveness criteria base on cognitive learning results (very effective $=\geq 80 \%$; effective $=70 \%-79 \%$, quite effective $=60 \%-69 \%$; less effective $=50 \%-59 \%$; not effective $<50 \%$ ) (Zulfiani et al., 2018).

\section{Data analysis}

Identify student learning style data adjusted for the appropriate rubric on the VARK Fleming instrument. After determining the learning style, then the percentage of visual, aural, reading/writing, and kinesthetic learning styles is carried out. Qualitative data, such as interviews with teachers about learning in grade $8^{\text {th }}$ junior high school and issues related to the use of instructional media, are analyzed by concluding the data.

Expert validation data were analyzed using a rating scale, which comprised five answer options numbered 0 to 4 (4, very good; 3 , good; 2 , sufficient; 1 , poor; 0 , very poor). The criteria for this rating scale were as follows. In order to draw conclusions from the media feasibility in each item, a percentage was used based on the overall score of all respondents to the overall respondents multiplied by a score of 4 . In order to identify the quality of the validated ALS media, a line scale conclusion was used (Sugiyono, 2014). For validation conclusions from experts, the Guttman scale was used. The applied instrument used a scale of "feasible" or "not feasible" as follows: $0-50 \%$, not feasible; $51-100 \%$, feasible. The test data of the trial were analyzed for normality and 
homogeneity for the next paired-samples $t$-test with a level of confidence $\alpha=0.05$. In the summative evaluation, an independent-samples $t$-test was carried out, followed by an analysis of variance with a level of confidence of $\alpha=0.05$. All statistical analyses were performed using SPSS Statistics 22.0 software (IBM Corp., Armonk, NY, USA).

\section{FINDINGS AND DISCUSSION}

\section{Study of science and learning styles in grade eight SMP/MTS in South Tangerang}

The aim of this study is to introduce an Android version of ScEd-ALS as a science learning medium with a variety of student learning styles. The research started with a qualitative study in the form of literature studies and field studies recommended for media development.

The results of the literature study generated important variables for the development of ScEd-ALS products as an Android version of science learning media. At this stage, identification of learning styles in three schools was tested. The learning style pattern of students aged 13-14 in South Tangerang Junior High School with 153 students in 2018 was predominantly unimodal rather than multimodal. The highest unimodal learning styles were as follows: aural (33\%), reading/writing (23\%), kinesthetic (20\%), and visual $(12 \%)$. The multimodal learning styles $(9 \%)$ consisted of the following: $5 \%$ visual kinesthetic, $2 \%$ visual aural, $1 \%$ aural reading/writing, $2 \%$ aural kinesthetic, $3 \%$ reading kinesthetic, and $1 \%$ visual aural reading/writing.

The results of teacher interviews from three grade eight SMP/MTS in South Tangerang are summarized in Table 2. The interviews showed that the integrated science study in the three SMP/MTS in South Tangerang used the curriculum of 2013. This conforms to what is stipulated in Permendikbud (Ministry of Education Regulation) number 22/2016 concerning process standards, wherein at the stage of SMP/MTS, lesson subjects shall maintain the integrated thematics in science. Nevertheless, in practice, there are two schools (i.e., SMP A and MTS B) at which integrated science is taught by two teachers with appropriate educational background (i.e., biology and physics).

Only at one school (i.e., MTS C) was integrated science taught by one teacher with biology as the educational background. This is as reported by Metri Dian Insanti (2016) that science teacher in Malang is dominated by Biology graduated. This is as reflected by science content for junior high school which is dominated by biology concept. 
Table 2

Interviews with teachers in the preliminary research.

\begin{tabular}{|c|c|c|c|c|}
\hline \multirow{2}{*}{ Indicator } & \multicolumn{3}{|l|}{ Teacher response } & \multirow{2}{*}{ Result } \\
\hline & SMP A & MTS B & MTS C & \\
\hline $\begin{array}{l}\text { Curriculum used at } \\
\text { school }\end{array}$ & Curriculum of 2013 & Curriculum of 2013 & $\begin{array}{l}\text { Curriculum of } \\
2013\end{array}$ & Curriculum of 2013 \\
\hline $\begin{array}{l}\text { Hours of studying } \\
\text { per week }\end{array}$ & $6 \mathrm{~h} /$ week & $6 \mathrm{~h} /$ week & $5 \mathrm{~h} /$ week & $6 \mathrm{~h} /$ week \\
\hline $\begin{array}{l}\text { Integrated science } \\
\text { study at school }\end{array}$ & $\begin{array}{l}\text { Integrated at lesson } \\
\text { plan. } \\
\text { Physics and biology } \\
\text { are taught } \\
\text { simultaneously in } \\
\text { the same week by } \\
\text { two teachers. }\end{array}$ & $\begin{array}{l}\text { Integrated. Physics } \\
\text { and biology are } \\
\text { taught by two } \\
\text { teachers. }\end{array}$ & $\begin{array}{l}\text { Integrated. } \\
\text { Physics and } \\
\text { biology are taught } \\
\text { by one teacher. }\end{array}$ & $\begin{array}{l}\text { Integrated. One } \\
\text { school provides one } \\
\text { teacher to teach } \\
\text { physics and biology, } \\
\text { and two schools } \\
\text { provide two teachers } \\
\text { for each of physics } \\
\text { and biology. }\end{array}$ \\
\hline $\begin{array}{l}\text { Evaluation of the } \\
\text { study }\end{array}$ & $\begin{array}{l}\text { Separated for daily } \\
\text { tests, but combined } \\
\text { for the final test. } \\
\text { Two subjects are } \\
\text { combined. } \\
\text { Per indicator } \\
\text { evaluation meeting. }\end{array}$ & $\begin{array}{l}\text { Separated for daily } \\
\text { tests, but combined } \\
\text { for the final test. } \\
\text { Two subjects are } \\
\text { combined. }\end{array}$ & $\begin{array}{l}\text { Separated for } \\
\text { daily tests, but } \\
\text { combined for the } \\
\text { final test. Two } \\
\text { subjects are } \\
\text { combined. }\end{array}$ & $\begin{array}{l}\text { Separated for daily } \\
\text { tests, but combined } \\
\text { for the final test. Two } \\
\text { subjects are } \\
\text { combined. }\end{array}$ \\
\hline $\begin{array}{l}\text { Training to } \\
\text { enhance teachers' } \\
\text { skills }\end{array}$ & $\begin{array}{l}\text { Training at group } \\
\text { level/MGMP }\end{array}$ & $\begin{array}{l}\text { Training at group } \\
\text { level/MGMP }\end{array}$ & $\begin{array}{l}\text { Training at group } \\
\text { level/MGMP }\end{array}$ & ailable. \\
\hline $\begin{array}{l}\text { Availability of } \\
\text { media and } \\
\text { computer-based } \\
\text { media }\end{array}$ & $\begin{array}{l}\text { Yes, there is a } \\
\text { school that provides } \\
\text { interactive CDs for } \\
\text { several concepts; a } \\
\text { computer lab is also } \\
\text { available }\end{array}$ & $\begin{array}{l}\text { Available media: } \\
\text { torso, science lab, } \\
\text { computer lab }\end{array}$ & $\begin{array}{l}\text { Available: torso, } \\
\text { science lab, } \\
\text { science kit, } \\
\text { computer lab } \\
\text { Study using } \\
\text { PowerPoint or } \\
\text { video }\end{array}$ & $\begin{array}{l}\text { Media availability is } \\
\text { sufficient }\end{array}$ \\
\hline $\begin{array}{l}\text { Use of } \\
\text { computers/laptops } \\
\text { in science lessons }\end{array}$ & Applicable & Yes, applicable & Yes, available & $\begin{array}{l}\text { Yes, computer labs } \\
\text { and laptops are } \\
\text { available }\end{array}$ \\
\hline $\begin{array}{l}\text { Teachers' } \\
\text { knowledge of } \\
\text { computer-based } \\
\text { media }\end{array}$ & Comprehend & Comprehend & Comprehend & Comprehend \\
\hline $\begin{array}{l}\text { Teachers' opinion } \\
\text { on the importance } \\
\text { of using computer- } \\
\text { based media to } \\
\text { enhance either the } \\
\text { study process or } \\
\text { remedial teaching }\end{array}$ & $\begin{array}{l}\text { It is important to } \\
\text { simplify the } \\
\text { concepts that } \\
\text { cannot be directly } \\
\text { tested in order to } \\
\text { help the students } \\
\text { understand them. }\end{array}$ & $\begin{array}{l}\text { Media are deemed } \\
\text { important. There are } \\
\text { both positive and } \\
\text { negative sides to } \\
\text { using media at home } \\
\text { (e.g., if media are } \\
\text { used at home, the } \\
\text { teacher would not be } \\
\text { able to know who } \\
\text { did the homework). }\end{array}$ & $\begin{array}{l}\text { Interesting, as } \\
\text { computer-based } \\
\text { media provide } \\
\text { attractive } \\
\text { visualizations and } \\
\text { very quick } \\
\text { responses }\end{array}$ & $\begin{array}{l}\text { Using media is } \\
\text { important in studying } \\
\text { and remedial } \\
\text { teaching. Media are } \\
\text { useful in providing } \\
\text { visualizations and } \\
\text { providing quick } \\
\text { responses in practice. }\end{array}$ \\
\hline
\end{tabular}

However, integrated science at the junior high school level demands the teachers to comprehend and integrate the concepts of physics, chemistry, and outer space.

International Journal of Instruction, April $2021 \bullet$ Vol.14, No.2 
Evaluation is conducted separately per subject (physics/biology). Training at the group level (MGMP) is quite active, which shows the teachers' efforts to increase their competence and networking skills. Susilowaty and Widhi (2015) reported the presence of the MGMP group, wherein teachers in SMPN 8 Jogjakarta use the RPP or lesson plan created by the MGMP with certain adaptation at the school level. Their research showed the introduction of integrated science in the lesson plan document, despite facing some problems in terms of skills.

Schools provide science study media facilities, science kits, interactive CDs, science labs, and computer labs. Teachers have sufficient skills in using computer-based learning media and other information technology media. Computer-based media are deemed interesting and convenient to comprehend as they provide picture/animation visualizations. As reported by Ichsan et al. (2018), using technology in teaching is very helpful for teachers. Research indicated the limited use of gadgets in junior high schools, leading to difficulties in developing learning media in the form of applications on mobile phones or websites.

\section{Android version of ScEd-ALS as a science learning medium}

\section{The design of ScEd-ALS}

The second stage (prototype) consists of the selection of the teaching material and the design of ScEd-ALS. The teaching material selected was related to motion and simple machine for the first semester of grade eight of the revised curriculum of 2013. The results of the material arrangement were adapted to four learning styles and then written in a storyboard. This storyboard experienced editorial changes after going through the validation stage by physics and biology experts (Figure 4).

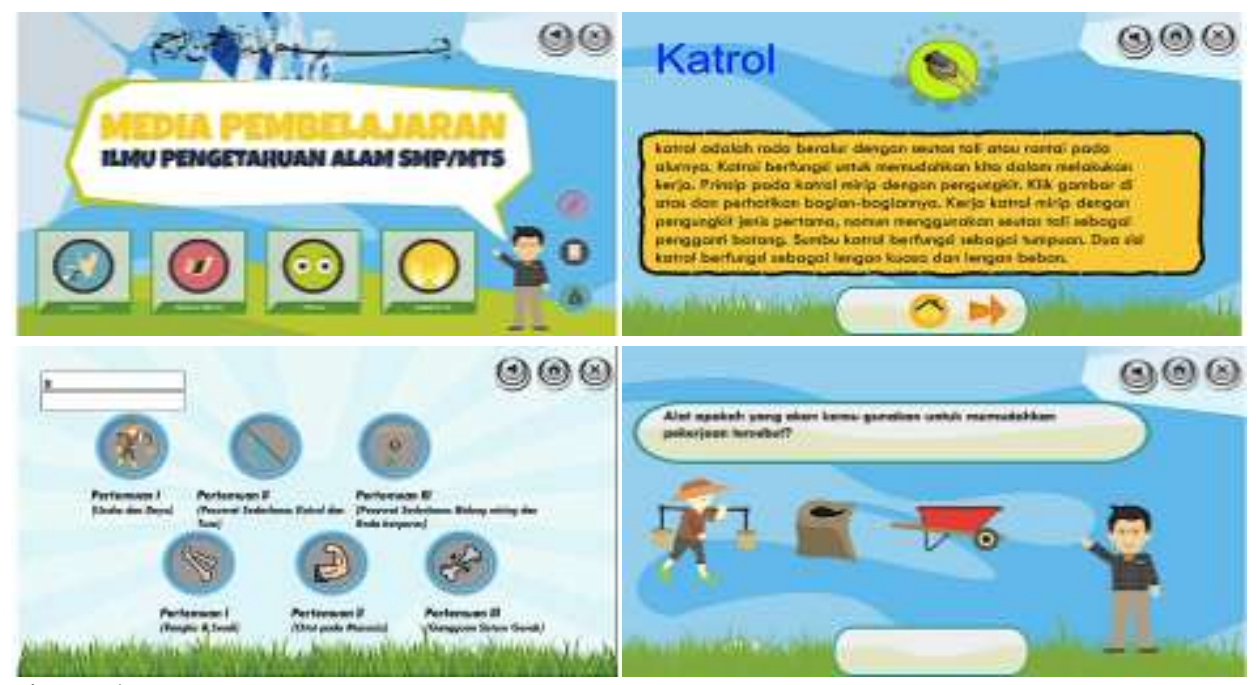

Figure 4

Examples of the display design of the ScEd-ALS. 


\section{Assessment results of the ScEd-ALS media according to experts}

The level of feasibility was assessed by five experts (two media experts and three science material experts). The media experts declared that the Android version of ScEdALS is good (mean score: 3 ) and feasible to use, (Table 3) and the science experts also stated that the learning media are very good (mean score: 4) and feasible to use (Table 4). (McKenney, \& Reeves, 2018)

Table 3

Assessment results of the ScEd-ALS media according to science experts

\begin{tabular}{llll}
\hline No & Indicator & Score & Conclusion \\
\hline 1 & $\begin{array}{l}\text { The suitability of pictures, animations, observation videos, and } \\
\text { explanatory videos related to the material }\end{array}$ & 4 & Very good \\
\hline 2 & $\begin{array}{l}\text { The clarity in explaining physics formulas and parts of organs } \\
\text { through learning texts or videos }\end{array}$ & 4 & Very good \\
\hline 3 & Clarity of sample problems on each material & 4 & Very good \\
\hline 4 & $\begin{array}{l}\text { The accuracy of the answers to the evaluation questions on each } \\
\text { material }\end{array}$ & 4 & Very good \\
\hline 5 & $\begin{array}{l}\text { The accuracy of the answers (systematic) and without } \\
\text { misconceptions on each material }\end{array}$ & 4 & Very good \\
\hline 6 & Material coverage and depth & 4 & Very good \\
\hline
\end{tabular}

Table 4

Assessment results of the ScEd-ALS media according to media experts

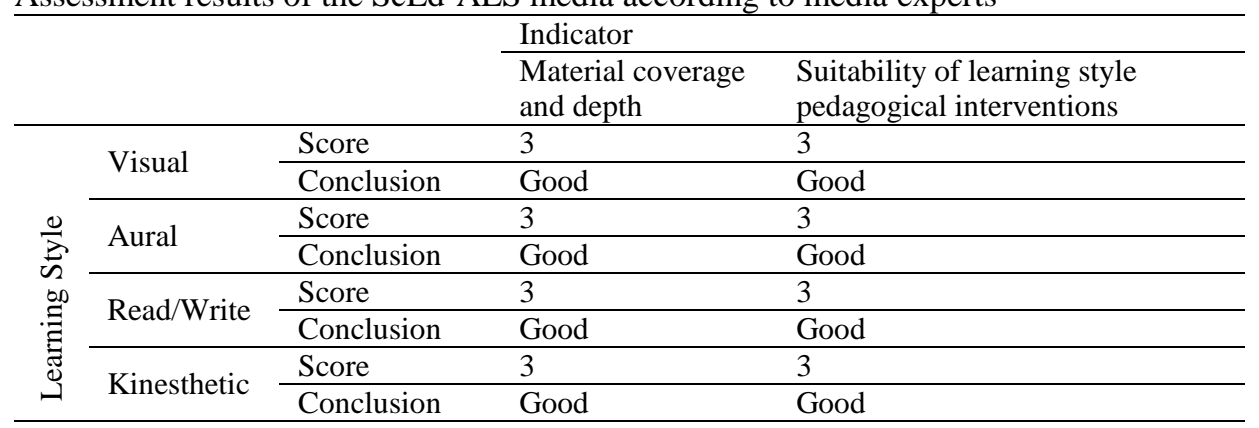

Validation from the experts regarding the Android version of the ScEd-ALS media suggested that the target of delivering material tailored to the students' learning styles has been achieved. It is recommended that additional integrated questions appear on the learning media so that the students get accustomed to constructing integrated science knowledge. The results of the overall indicators on the media with four learning styles were categorized as good. The next step was to improve the media according to the material or media validator's advice.

Assessment results of each aspect of the media on one-to-one evaluation

The results of the one-to-one evaluation of the ScEd-ALS media were considered to be good, such as the aspect for material, learning design, implementation, and technical 
quality (mean score: 3 ), with the highest response in the implementation aspect (very good, mean score: 4).

\section{Small group phase result}

The results of the small group test that was carried out in the blended learning design indicated a significant difference in the student learning outcomes $(p<0.05)$ before and after using the Android version of the ScEd-ALS media, as shown in Table 5. The small group trial was guided by two physics and biology teachers as stipulated in the school policy, wherein integrated science subjects are taught by two teachers.

Table 5

Small group paired-samples test results.

\begin{tabular}{llll}
\hline Indicator & Mean/SDV & Normality & $t$-test \\
\hline Pretest/SDV & $37 / 11.8$ & $0.2 /$ Sig. & $\mathrm{df}(23) / 0.000 *$ \\
\hline Posttest/SDV & $61.5 / 12$ & $0.2 /$ Sig. & *Significant \\
\hline
\end{tabular}

\section{Field test phase result}

The results of the statistical tests with paired-samples tests on the field test showed that there were significant differences in the learning outcomes before and after learning using the Android version of the ScEd-ALS media, wherein students experienced a significant improvement as shown in Table 6.

Table 6

Paired-samples $t$-test field test results.

\begin{tabular}{llll}
\hline Indicator & Mean/SDV & Normality & $t$-test \\
\hline Pretest/SDV & $29.00 / 5.7$ & $0.2 /$ Sig. & df $(22) / 0.000^{*}$ \\
\hline Posttest/SDV & $56.17 / 5.9$ & $0.2 /$ Sig. & $*$ Significant \\
\hline
\end{tabular}

In the field test phase, learning is guided by two teachers who teach integrated science subjects with a cooperative learning design. Students' responses to learning media are considered as good (mean score: 3) such as aspect: material, learning design, implementation, and technical quality.

\section{Effectiveness of the ScEd-ALS media}

The third stage is the summative evaluation. The statistical test results of the independent-samples $t$-test showed that there were significant differences in the learning outcomes in the experimental and control classes $(\alpha=0.05, p<0.05)$, as shown in Table 7. Teaching is conducted by one science teacher within the blended learning setting.

Table 7

Independent-samples $t$-test.

\begin{tabular}{lll}
\hline Indicator & Experiment & Control \\
\hline Pretest/SDV & $35.26 / 7.13$ & $32.67 / 6.61$ \\
\hline Posttest/SDV & $57.96 / 5.65$ & $53.67 / 7.47$ \\
\hline Normality & $0.2(p>0.05)=$ normal \\
\hline Homogeneity & $F(0.835)=0.365(\mathrm{p}>0.05)=$ homogen. \\
\hline$t$-test & df $48=0.026(p<0.05)$, significant \\
\hline
\end{tabular}


The results of the experiment class's posttest with visual learning styles gained the highest mean (64.41), read/write (58), kinesthetic (57), and aural (53). One-way analysis of variance (ANOVA) statistical test showed that there is no difference in the variation of learning styles toward student learning outcomes $(p=0.158, p>0.05)$, as shown in Table 8.

Table 8

ANOVA test

\begin{tabular}{llllll}
\hline & Sum of squares & df & Mean square & $F$ & Sig. \\
\hline Between groups & 164.689 & 3 & 54.896 & 1.913 & 0.158 \\
\hline Within groups & 602.589 & 21 & 28.695 & & \\
\hline Total & 767.279 & 24 & & & \\
\hline
\end{tabular}

The effectiveness of the media on the achievement of learning outcomes shows variation. (Table 9) ScEd-ALS android based on visual and kinesthetic learning styles are the most effective media compared to aural (less effective) and read/write (not effective).

Table 9

Learning cognitive result base on learning style

\begin{tabular}{llll}
\hline Learning Style & Number of Students $(\mathrm{N})$ & N Mastery & Effectiveness $(\%)$ \\
\hline Visual & 4 & 3 & 75 \\
\hline Aural & 6 & 3 & 50 \\
\hline Read/write & 11 & 5 & 46 \\
\hline Kinesthetic & 4 & 3 & 75 \\
\hline
\end{tabular}

The students' responses to the use of ScEd-ALS are considered to be good. Their response was very good (mean score: 4) on the presentation techniques, whereas the material aspects, learning design, and implementation fell in the good category (mean score: 3 ).

Thus, the effectiveness of the media can be concluded quite effective in improving student learning outcomes that are reinforced by the results of student responses in either category. The effectiveness of using ScEd-ALS in this study was measured based on the percentage of students' mastery level. This research is said to be effective; at least $55 \%$ of the study's sample is complete in its research. Student mastery is measured based on the success of students passing a specific score limit, or the percentage of students who complete at least $55 \%$ of the total number of students per the learning style. The instrument used to measure students' mastery is the concept mastery test. This instrument is given to all learning styles. The percentage of completeness is calculated by comparing the number of students completed to the number of students in each learning style.

There is a significant difference in the learning outcomes between students using the Android version of ScEd-ALS and the control class (not using the Android version). These results are in line with the study of Ahmar and Rahman (2017). It is seen that students could understand the material and practical training faster and more easily with 
Android-based teaching and were better prepared with the subject material. Likewise, Wardani, Lindawati \& Kusuma (2017) reported the use of an android-based digital game with the essence of subject matter, namely the Chemistry Board Game (CBG) of Al Chemist Knight, can improve students' cognitive learning and critical thinking of students.

\section{DISCUSSION}

Ubiquitous learning (U-learning) has recently gained increased popularity in the field of education. The key factors of U-learning are that students are in a "context-aware" learning environment and that they may not even realize that they are studying (Hwang et al., 2014; Sahrir, Yahaya, Nasir, \& Hamid, 2018). U-learning-based media have the capability to provide content to students appropriately and adaptively. As a result, developing ULE significantly increases the learning efficiency both individually and collaboratively. Students were very satisfied when they learned through ULE about the aspects of function and adaptability (Kim, 2011; Liu, Liu, Lin, Kuo, \& Hwang, 2016; Kang \& Kim, 2015).

One of the technical drawbacks observed during this study is school flexibility in facilitating the conduct of research. There were still technical constraints in that the students must leave their mobile phones before class to roster teachers, which leads to the lack of effectiveness in terms of time and preparation of students when learning integrated science. This result is in line with the research of Rahman, Hidayat, \& Yanuttama (2017) on developing Android-based learning media in Indonesia. It was found that the use of Android-based augmented reality facilitates the delivery of material to students and emphasizes the importance of the stakeholders' role in the effectiveness of the information exchange process. The second drawback is the lack of ownership of handphones/smartphones in learning. In both the experiment and the control classes, the presence of smartphones was only two or three pieces per group (one group of four or five people), leading to low accessibility for students in using media more freely. The third drawback was that there were some constraints on the Android devices in accessing ScEd-ALS, and hence some supporting software was needed, such as Adobe IR and SWF players. Some devices owned by the students had a limited memory capacity, causing failures in downloading and, hence, the lack of media availability in one study group. In contrast, the research results of Pruet et al., (2016) showed a significant effect of using mobile devices in learning on learning outcomes, especially for students with visual learning styles. In their research, they reported that tablet-shaped mobile devices are prepared by the school. This shows that the technical constraints faced in this research will be minimalized if the provision of mobile devices is supported by the school system. The fourth drawback is that the setting of the learning strategies in the experimental class was the blended learning model, which is adjusted to the fact that the students are not yet fully independent; hence, material intervention by teachers in the classroom is still very much needed. Using the Android operating system has ultimately become a reference supplement and assignment/problem training for students. The fifth drawback is that the evaluation instruments and the applied evaluation instruments are 
still conventional (i.e., using knowledge measurement techniques that disregard student learning styles).

U-learning-based media development has been widely studied. It is very important to speed up the development of smartphones for media-based learning, which is actually in line with the increasing research related to this subject carried out from 2001 to 2010 in multiple countries. This has become the basis of developmental research. An educator needs to place students to learn in the real world (Lave \& Wenger, 1991), and cellular technology and communication can be a key component in supporting effective learning in the real world (Hwang, Kuo, Yin, \& Chuang, 2010; Park, 2011).

Relevant research concerning the development of Android-based media may help governmental policymakers and researchers from professional organizations allocate the necessary resources and create plans to support future research and applications (Hwang \& Tsai, 2011).

\section{CONCLUSION}

It was found that the Android version of ScEd-ALS is feasible. This feasibility was assessed by five experts (two media experts and three science material experts). The media experts declared that the Android version of ScEd-ALS is good and feasible to use, and the material experts stated that the learning media are very good and feasible to use. There was a significant difference in the learning outcomes of students using the Android version of ScEd-ALS compared to the control class (not using the Android version). The results of the posttest experiment class with visual learning styles gained the highest mean (64.41), read/write (58), kinesthetic (57), and aural (53). One-way ANOVA statistical test showed that there was no difference in the variation of learning styles toward student learning outcomes. The effectiveness of using ScEd-ALS in this study was measured based on the percentage of students' mastery level. ScEd-ALS Android based on visual and kinesthetic learning styles are the most effective media compared to aural and read/write. ScEd-ALS media are an alternative science learning medium that accommodates variations in learning styles. Further research is needed on more ideal school settings so as to demonstrate the differences in the student learning outcomes with variations in the learning styles. Applying Android-based media in Indonesia is still facing some technical difficulties, such as the school support system, low capacity of the smartphone devices owned by the students, and readiness of teachers and students to adapt to information-technology-based media devices.

ScEd-ALS media provide an opportunity for students to conduct self-regulation regarding the acquisition of their knowledge. ScEd-ALS media have been adapted to the stages of constructive learning, wherein besides accommodating the material, the media also help improve the students' thinking skills in order to achieve competence according to the learning objectives. As such, teachers need to be assured that the students are able to learn independently while maintaining supervision. 


\section{ACKNOWLEDGEMENT}

The researchers would like to thank PUSLIPTEN LP2M UIN Syarif Hidayatullah Jakarta for the applied research and development of tertiary institutions grant in 2018.

\section{REFERENCES}

Ako-Nai, F.,Qing, T., Pivot, F., \& Kinshuk. (2012). The 5R Adaptive Learning Content Generation Platform for Mobile Learning. IEEE Fourth International Conference on Technology for Education (T4E), 132-137.

Ahmar, A., \& Rahman, A. (2017). Development of teaching material using an Android. Global Journal of Engineering Education, 19(1), 72-76.

Akker, J.J.H van den., Gravemeijer, K., McKenney, S Nieveen, N. (2006). Educational Desian Research (1st ed.). Abingden, Oxon : Routledge Publishers.

Al-Azawei, A., \& Badii, A. (2014). State of the art of learning styles-based adaptive educational hypermedia systems (LS-BAEHSs). International Journal of Computer Science \& Information Technology, 6(3), 1-19.

Astiningsih, A.D., \& Partana, C.F. (2020). Using Android Media for Chemistry Learning Construction of Motivation and Metacognition Ability. International Journal of Instruction, 13(1), 279-294.

Arista, F. S., \& Kuswanto, H. (2018). Virtual Physics Laboratory Application Based on the Android Smartphone to Improve Learning Independence and Conceptual Understanding. International Journal of Instruction, 11(1), 1-16.

Baeten, M., Dochy, F., Struyven, K., Parmentier, E., \& Vanderbruggen, A. (2015). Student-centred learning environments: an investigation into student teachers' instructional preferences and approaches to learning. Learning Environments Research, 19(1), 43-62. https://doi.org/10.1007/s10984-015-9190-5.

Balakrishnan, V., \& Gan, C. L. (2016). Students' learning styles and their effects on the use of social media technology for learning. Telematics and Informatics, 33(3), 808821. https://doi.org/10.1016/j.tele.2015.12.004.

Birch, D., Sankey, M., \& Gardiner, M. (2010). The impact of multiple representations of content using multimedia on learning outcomes. International Journal of Instructional technology and distance learning, 7(4), 3-19.

Calimag, J. N., Mugel, P. A., Conde, R. S., \& Aquino, L. B. (2014). Ubquitous learning environment using android mobile application. International Journal of Research in Engineering \& Technology, 2(2), 119-128.

Cohen, L., Manion, L., \& Morrison, K. (2011). Surveys, longitudinal, cross-sectional and trend studies. Research Methods in Education, 7th edition. Abingdon: Routledge, 261-4. 
de-Marcos, L., Hilera, J. R., Barchino, R., Jiménez, L., Martínez, J. J., Gutiérrez, J. A., ... \& Otón, S. (2010). An experiment for improving students performance in secondary and tertiary education by means of m-learning auto-assessment. Computers \& Education, 55(3), 1069-1079.

Dunn, R., Beaudry, J. S., \& Klavas, A. (2002). Survey of research on learning styles. California Journal of Science Education, 2(2), 75-98.

Dwi, S. (2016). The role of mobile learning on the learning environment shifting at high school in Indonesia. Internationa journal of mobile leaning and organisation, 10(3), 159-170.

Echenique, E. G., Molías, L. M., \& Bullen, M. (2015). Students in higher education: Social and academic uses of digital technology. International Journal of Educational Technology in Higher Education, 12(1), 25-37.

eMarketer. (2014). Retrieved on March 2014 from https://www.emarketer.com/Webinar/Key-Digital-Trends-2014/4000075.

Farida, I. I. (2018). Developing Android-Based Science Instructional Media to Improve Scientific Literacy of Junior High School Students. Journal of Physics: Conference Series, $1006(1), 012034$.

FernáNdez-LóPez, Á., RodríGuez-FóRtiz, M. J., RodríGuez-Almendros, M. L., \& MartíNez-Segura, M. J. (2013). Mobile learning technology based on iOS devices to support students with special education needs. Computers \& Education, 61, 77-90.

Fleming, N. (2017). The VARK Questionaire. Retrieved from http:// www.varklearn.com/english/page.asp? $\mathrm{p}=$ younger.

Hwang, G. J., \& Tsai, C. C. (2011). Research trends in mobile and ubiquitous learning: A review of publications in selected journals from 2001 to 2010. British Journal of Educational Technology, 42(4), E65-E70.

Hwang, G.H., Chu, C.H. Chen B., Cheng, S.Z. (2014). Development and Evaluation of a Web 2.0-Based Ubiquitous Learning Platform for Schoolyard Plant Identification. International Journal of Distance Education Technologies, 12(2), 83-103.

Ichsan, I. Z., Dewi, A. K., Hermawati, F. M., \& Iriani, E. (2018). Pembelajaran IPA dan lingkungan: analisis kebutuhan media pembelajaran pada SD, SMP, SMA di Tambun Selatan, Bekasi. JIPVA (Jurnal Pendidikan IPA Veteran), 2(2), 131-140.

Jelatu, S., Kurniawan, Y., Kurnila, V. S., Mandur, K., \& Jundu, R. (2019). Collaboration TPS Learning Model and m-Learning Based on Android for Understanding of Trigonometry Concepts with Different Cognitive Style. International Journal of Instruction, 12(4), 545-560.

Kang, B. H., \& Kim, H. (2015). Proposal: A design of u-learning module application for multi-cultural students in Korea. International Journal of Software Engineering and Its Applications, 9(1), 167-172. 
Kim, H. J. (2011). Educational Paradigm Shift from E-Learning to Mobile Learning Toward Ubiquitous Learning. Journal of the Korea Academia-Industrial Cooperation Society, 12(11), 488-4795.

Klašnja-Milićević, A., Vesin, B., Ivanović, M., \& Budimac, Z. (2011). E-Learning personalization based on hybrid recommendation strategy and learning style identification. Computers \& Education, 56(3), 885-899.

Lave, J., \& Wenger, E. (1991). Situated learning: Legitimate peripheral participation. Cambridge: Cambridge University Press. http://dx.doi.org/10.1017/CBO9780511815355.

Lemke, C. (2013). Intelligent adaptive learning: an essential element of 21 st century teaching and learning. Bellevue, wa: dreambox learning.

Liu, G. Z., Liu, T. C., Lin, C. C., Kuo, Y. L., \& Hwang, G. J. (2016). Identifying learning features and models for context-aware ubiquitous learning with phenomenological research method. International Journal of Mobile Learning and Organisation, 10(4), 238-262.

Liliarti, N., \& Kuswanto, H. (2018). Improving the Competence of Diagrammatic and Argumentative Representation in Physics through Android-Based Mobile Learning Application. International Journal of Instruction, 11(3), 107-122.

Liu, T. Y., \& Chu, Y. L. (2010). Using ubiquitous games in an English listening and speaking course: Impact on learning outcomes and motivation. Computers \& Education, 55(2), 630-643.

Magdalena, S. M. (2015). The Relationship of Learning Styles, Learning Behaviour and Learning Outcomes at the Romanian Students. Procedia - Social and Behavioral Sciences, $\quad 180 \quad$ (November 2014), 1667-1672. https://doi.org/10.1016/j.sbspro.2015.05.062.

McKenney, S., \& Reeves, T. C. (2018). Conducting educational design research. Routledge.Norris, D., Mason, J., \& Lefreve, P. (2003). Trasforming e-knowledge: A revolution in the sharing of knowledge. Ann Arbor, MI: The society for College \& University Planning.

OO de Pietro. (2013). Authentic and Situated Learning with the Use of an Adaptive Search Engine and a QR-Code in Mobile Mode. International Journal of Digital Literacy and Digital Competence, 4(3), 19-30.

Park, Y. (2011). A pedagogical framework for mobile learning: Categorizing educational applications of mobile technologies into four types. The international review of research in open and distributed learning, 12(2), 78-102.

Pham, H. L. (2012). Differentiated instruction and the need to integrate teaching and practice. Journal of College Teaching \& Learning (TLC), 9(1), 13-20. 
Puspitasari, L., \& Ishii, K. (2016). Digital divides and mobile Internet in Indonesia: Impact of smartphones. Telematics and Informatics, 33(2), 472-483.

Park, Y. (2011). A pedagogical framework for mobile learning: Categorizing educational applications of mobile technologies into four types. The international review of research in open and distributed learning, 12(2), 78-102.

Pruet, P., Ang, C. S., \& Farzin, D. (2016). Understanding tablet computer usage among primary school students in underdeveloped areas: Students' technology experience, learning styles and attitudes. Computers in Human Behavior, 55, 1131-1144.

Rahman, A. Z., Hidayat, T. N., \& Yanuttama, I. (2017). Media Pembelajaran Ipa Kelas 3 Sekolah Dasar Menggunakan Teknologi Augmented Reality Berbasis Android. [Science learning media for 3 grader elementary school student using android-based augmented reality technology]. Semnasteknomedia Online, 5(1), 4-6.

Sahrir, M. S., Yahaya, M. F., Nasir, M. S., \& Hamid, M. F. A. (2018). Design and Development of Mobile EZ-Arabic. Net for Ubiquitous Learning Among Malaysian Primary School Learners from Experts' Perspective. In Mobile and Ubiquitous Learning (pp. 341-361). Springer, Singapore.

Suwarna, I.P. (2017). Problematika Pembelajaran Fisika dan Penggunaan Teknologi di Sekolah. [Problems of Learning Physics and Using Technology in Schools]. Unpublished manuscript.

Sunarto, M. J., Hariadi, B., Sagirani, T., Amelia, T., \& Lemantara, J. (2020). MoLearn, a Web-and Android-Based Learning Application as an Alternative for TeachingLearning Process in High Schools. International Journal of Instruction, 13(1), 54-70.

Sugiyono. (2014). Statistik untuk Penelitian [Statistics for Research]. Bandung, Indonesia: Alfabeta.

Tessmer, Martin. (1993). Planning and Conducting Formative Evaluations. London: Routledge.

Tigrek, S., \& Obadat, M. (2012). Teaching smartphones programming using (Android Java): Pedagogy and innovation. In Information Technology Based Higher Education and Training (ITHET), International Conference on (pp. 1-7). (IEEE).

Wen, S. M. L., \& Liu, T.C. (2016). Reconsidering teachers' habits and experiences of ubiquitous learning to open knowledge. Computers in Human Behavior, 55, 1194-1200.

Valk, J.H., Rashid, A.T., \& Elder, L. (2010). Using mobile phones to improve educational outcomes: An analysis of evidence from Asia. The International Review of Research in Open and Distributed Learning, 11(1), 117-140.

Van De Bogart, W.G. (2012). Developing Multi-literacy Skills in e-Learning Environments using Tablet Computers at the Primary Grade Level in Thailand. In International e-Learning Conference 2012 (IEC2012). 
Wardani, S., Lindawati, L., \& Kusuma, S. B. W. (2017). The development of inquiry by using android-system-based chemistry board game to improve learning outcome and critical thinking ability. Jurnal Pendidikan IPA Indonesia, 6(2), 196-205.

Zulfiani, Z., Suwarna, I. P., \& Miranto, S. (2018). Science Education Adaptive Learning System As A Computer-Based Science Learning With Learning Style Variations. Journal of Baltic Science Education, 17(4). 